\title{
Performance characteristics of growing indigenous guinea fowls from upper east, upper west and Northern regions of Ghana
}

\author{
Agbolosu, A. A., Teye, G. A., Adjetey, A. N. A., Addah, W. and Naandam, J \\ Animal Science Department, University for Development Studies, P. O. Box TL 1882, Tamale \\ Tel: 2330246388872. \\ Corresponding Author's email address: anthonyagbolosu@yahoo.com
}

\begin{abstract}
A growth performance study on 240, eight week old local guinea fowls from Upper East, Upper West and Northern regions of Ghana was conducted at the University for Development Studies, Tamale. Each treatment consisted of 20 birds per region per cage with four replicates. Birds were fed iso-caloric $(2800 \mathrm{Kcal} / \mathrm{Kg})$ and iso-protein $(20 \% \mathrm{CP})$ grower diets. Water was provided ad libitum. Parameters measured were feed intake, weight gain, feed conversion efficiency, mortality, egg productivity (total number of eggs), egg infertility and egg fertility. There were significant differences $(P<0.05)$ in feed intake of birds. Birds from Northern region had the highest intake of $78.3 \pm 3.54 \mathrm{~g} / \mathrm{bird} / \mathrm{day}$ followed by birds from Upper East $(74.4 \pm 3.54 \mathrm{~g} / \mathrm{bird} /$ day $)$ and Upper West $(62.9 \pm 3.54 \mathrm{~g} / \mathrm{bird} /$ day). Daily weight gain and feed conversion efficiency of the birds from all three regions were not significantly different $(P>0.05)$. Birds from Upper West region suffered the highest mortality (17.5\%), with the least being those from Upper East (1.25\%). Total eggs laid during the period were 362 eggs for Northern region, 310 eggs for Upper East and 266 for Upper West. These also showed significant differences $(\mathrm{P}<0.001)$. Egg fertility levels were satisfactory in birds from all three regions (77.4-81.9\%). There were distinctive differences in almost all the parameters measured. This can provide the basis for which they could be classified into breeds.
\end{abstract}

Keywords: Guinea fowl, growth performance, mortality, fertility, infertility

\section{INTRODUCTION}

The guinea fowl (Numida meleagris) originate in Africa where today some still remain in the wild (Dei and Karbo, 2004). It is one of the most common poultry species found in northern Ghana. It has different strains, which include Pearl, White and the Lavendar guinea fowls (Dei and Karbo, 2004). The commonest strain found in these regions is the pearl guinea fowl. It has a purplish-gray plumage, dotted or pearled with white. Guinea fowls are mostly raised as scavengers together with domestic village poultry (Kashindye, 2000). The birds are usually kept in households in small numbers as a source of protein for the family.

In spite of the importance and advantages of guinea fowls over other poultry species in Northern Ghana there is still a paucity of scientific research on the management problems of local guinea fowl production, in contrast to indigenous chickens (Awotwi, 1987; Maganga and Haule, 1994). These problems include poor hatchability of eggs, male infertility, high keet mortality, difficulty in sexing keets, slow growth rate and a dearth of knowledge on the genetic improvement (Oke et al., 2004), nutrient requirements and prophylactic health management practices.

Significant strides were made under the Smallholder Agricultural Development Project (SADEP) of IFAD in terms of management of both local and exotic breeds under intensive management. Further research activities and transfer of the knowledge developed include work on brooding management of local guinea fowls on-farm in some selected farmers' farms around Nyankpala.

The Animal Science Department of UDS recognizes the socio-economic importance of the guinea fowl in Northern Ghana in particular and the whole country in general and the need to pursue the local guinea fowl improvement programme. Aspects of guinea fowl research considered include maintenance and improvement as well as conservation of the indigenous breeds to prevent extinction. This study was therefore to obtain basic information on the growth performance with its objective being to compare the growth performance of growing guinea fowls in relation to the particular environment from 
which they are raised as keets, determine whether a change in environment (housing systems, feeding and medication) will improve growth performance and lastly evaluate levels of performance.

\section{MATERIALS AND METHODS}

Study area: The experiment was carried out at the Animal Science Department farm of the University for Development Studies, Nyankpala campus, Tamale. Nyankpala is located about $16 \mathrm{Km}$ West of Tamale and lies on latitude 92541 and longitude 05842 West in the Guinea Savanna zone. It has an average annual rainfall of $1034.4 \mathrm{~mm}$. Mean annual daytime humidity is $54 \%$ with relative humidity usually high in the morning and low at night. Annual temperature is $28.3^{\circ} \mathrm{C}$ (SARI, 2004). The study area is characterized by low, seasonal, unimodal and poorly distributed rainfall. The dry season lasts for about six to seven months.

Duration of experiment: The experiment was conducted over a period of 70 days between February to the end of April 2006. Two weeks was used as an adjustment period and eight weeks for data collection.

Procurement of birds: Two hundred and forty, eight week old guinea fowls were obtained from the three northern regions of Ghana (Upper West, Upper East and Northern regions). 80 birds per region were obtained and the sex ratio was 20 males to 60 females (1:3). Local farmers helped sex the birds using comb identification whereas the researchers confirmed this using vent sexing (rudimentary phallus method). Good health status was a criterion for selection of birds.

Management of experimental birds: The birds were housed in a deep litter floored house each of size $21 \mathrm{ft}$ by $21 \mathrm{ft}$. Each room had six cages each of size $8 \mathrm{ft}$ by $7 \mathrm{ft}$. Each cage contained a total of twenty birds, in the ratio of $1: 3$ that is five males to fifteen females. Feed and water were provided ad libitum.

Feeding: Grower concentrate, maize and wheat bran were the main ingredients in the diet. Maize was obtained from the Tamale market whereas the wheat bran and concentrate were obtained from Agricare Feed Limited, Tamale. The ingredient composition in the experimental diet was $30 \%$ concentrate, $50 \%$ maize and $20 \%$ wheat bran per $100 \mathrm{Kg}$. The feed formulated contained $20 \%$ crude protein and 2800 $\mathrm{Kcal} / \mathrm{Kg}$ metabolizable energy.

Experimental design: Completely randomized design was used with regions considered as treatments. Birds from the various regions were randomly allocated to the various cages. There were three treatments with four replications per treatment. Each replicate comprised twenty birds.

Parameters measured: The parameters measured for the growth performance included feed intake, live weight gain, final live weight, mortality, feed conversion ability (weight gain/feed intake; excluding egg production), and productivity (egg fertility, infertility and total eggs produced over the period). Feed consumption and weight of birds were measured weekly.

Statistical Analysis: Data was analyzed by Analysis of variance (ANOVA) using GENSTAT seventh edition program (Lawes Agricultural Trust, 1995) and significantly different means were separated using the least significant test at $5 \%$ level.

\section{Results and Discussion:}

Performance: Results of the comparative study on growth performance of growing guinea fowls are shown in Table 1.

Table 1: Feed intake, body weight, weight gain and feed conversion efficiency

\begin{tabular}{|l|c|c|c|c|}
\hline \multirow{2}{*}{ Parameters } & \multicolumn{3}{|c|}{ Regions } & \multirow{2}{*}{ × s.e.d } \\
\cline { 2 - 4 } & $\begin{array}{c}\text { Upper } \\
\text { East }\end{array}$ & $\begin{array}{c}\text { Upper } \\
\text { West }\end{array}$ & Northern & \\
\hline $\begin{array}{l}\text { Feed intake } \\
\text { /bird/day (g) }\end{array}$ & $74.4^{\mathrm{a}}$ & $62.9^{\mathrm{b}}$ & $78.3^{\mathrm{a}}$ & $3.54^{*}$ \\
\hline $\begin{array}{l}\text { Body } \\
\text { weight/bird/week } \\
\text { (g) }\end{array}$ & $1248.0^{\mathrm{a}}$ & $1054.0^{\mathrm{b}}$ & $1148.0^{\mathrm{C}}$ & $26.5^{*}$ \\
\hline $\begin{array}{l}\text { Weight } \\
\text { gain/bird/day (g) }\end{array}$ & 7.1 & 6.8 & 6.2 & $1.79^{\mathrm{NS}}$ \\
\hline $\begin{array}{l}\text { Feed conversion } \\
\text { efficiency }\end{array}$ & 1.02 & 1.03 & 0.82 & $0.231^{\mathrm{NS}}$ \\
\hline
\end{tabular}

Means with different letters in the same row are significantly different $\left({ }^{\star} P<0.05\right)$; s.e.d-Standard Error of difference; NS - Not significant $(P>0.05)$

Feed intake: Feed intake of Upper West birds was lower and differed significantly $(\mathrm{P}<0.05)$ from those of Northern and Upper East regions, whereas feed intake of birds from the latter two regions showed no significant difference $(P>0.05)$, implicating differences in environmental conditions that probably called for longer adjustment and/or adaptive period for birds from Upper West because they ate less (Table 1). Apart from environmental condition, feed intake is affected by factors such as body size (Oke et al., 
2004). It was observed from the experiment that birds from Upper West region were generally smaller compared to their counterparts from Northern and Upper East regions. This could further account for the lower feed intake of birds from Upper West compared to birds from Northern and Upper East regions. However during the latter parts of the experiment feed intake gradually improved.

Body weight: There were significant differences $(\mathrm{P}<0.05)$ in body weight of birds from all the three regions. This observation may be due to their source and genetic makeup. Ayorinde and Oke (1995) indicated that body weight within a flock can be attributed to genetic variation and environmental factors that impinge on individuals.

Generally weekly body weights of the birds increased as feed intake also increased; however the body weight of birds from Northern region did not reflect their feed intake (Table 1). It was expected that since birds from Northern region ate more feed than birds from the other regions, their body weight should have been the highest, but this was not the case. The low body weight could be attributed to the high total egg production as depicted in Tables 1 and 3 . Although there were no significant differences $(P>0.05)$ in feed intake (Table 1) and egg numbers (Table 3 ) between birds from Upper East and Northern region, there was a significant difference $(P<0.05)$ in body weight, probably suggestive of differences in feed conversion abilities, an obvious genetic trait.

Weight gain: From Table 1, there was no significant difference $(P>0.05)$ between the daily weight gain of birds from all the three regions, however birds from Upper East had the highest weight gain even though they performed averagely in egg numbers, hinting at a higher innate potential for feed conversion.

Weight gains were higher for birds from Upper West than those from Northern region, even though feed intake was the reverse. This may be ascribed to the fact that birds from Northern region had higher nutritional requirement due to their higher performance in egg production.

Feed Conversion Efficiency: There was no significant difference $(P>0.05)$ in feed conversion ability between birds from the three regions (Table 1 ), though there tended to be difference in absolute terms, which suggested that a lower confidence level of testing could probably lead to significance. This indicates that though feed conversion efficiency among birds from the various regions appear the same for the given $\alpha$-level of testing above, the potential to convert the feed into either eggs or meat varied among the birds. This confirms earlier findings by Teye et al. (2001) that the indigenous guinea fowl has a high potential for feed conversion, which can be improved with intensive selection of outstanding individuals.

Mortality: Death was recorded among birds from the three regions with higher percentage mortality $(17.5 \%)$ in birds from Upper West region. Northern region recorded $8.8 \%$ mortality while Upper East recorded the least with $1.3 \%$ mortality (Table 2 ). The Upper East region birds seemed hardier possibly because of the comparative extreme climatic conditions they were coming from.

Table 2: Mortality and Survival during experimental period

\begin{tabular}{|l|c|c|c|}
\hline \multirow{2}{*}{ Parameters } & \multicolumn{3}{|c|}{ Regions } \\
\cline { 2 - 4 } & $\begin{array}{c}\text { Upper } \\
\text { East }\end{array}$ & $\begin{array}{c}\text { Upper } \\
\text { West }\end{array}$ & Northern \\
\hline $\begin{array}{l}\text { Total number of } \\
\text { birds }\end{array}$ & 80 & 80 & 80 \\
\hline $\begin{array}{l}\text { Total number } \\
\text { dead }\end{array}$ & 1 & 14 & 7 \\
\hline $\begin{array}{l}\text { Number of } \\
\text { survival }\end{array}$ & 79 & 66 & 73 \\
\hline $\begin{array}{l}\text { Percentage } \\
\text { survival (\%) }\end{array}$ & 98.7 & 82.5 & 91.3 \\
\hline $\begin{array}{l}\text { Percentage } \\
\text { mortality (\%) }\end{array}$ & 1.3 & 17.5 & 8.8 \\
\hline
\end{tabular}

Post mortem results showed that majority of deaths were as a result of starvation and worm infestation. Initially, birds were off feed because of the change in environment (system of housing, location) and change in the type of feed eaten by the birds. Teye and Gyawu (2002) reported that mortalities during the growing period are often due to parasitic infections (worms, bacteria, coccidiosis and staphylococcus). This agrees with the post mortem results that most of the birds died as a result of worm infestation.

Productivity: 
Agric. Biol. J. N. Am., 2012, 3(8): 336-339

Table 3: Total number of eggs laid within the period of experiment and their egg fertility and infertility ratios.

\begin{tabular}{|c|c|c|c|c|c|}
\hline \multirow[b]{2}{*}{ Parameters } & \multicolumn{3}{|c|}{ Regions } & \multirow[b]{2}{*}{ s.e.d } & \multirow[b]{2}{*}{ Significance } \\
\hline & Upper East & Upper West & Northern & & \\
\hline Total number of eggs & $301^{b}$ & $266^{C}$ & $362^{a}$ & 0.816 & $\star \star * *$ \\
\hline Number of fertile eggs & $240^{b}$ & $218^{C}$ & $291^{a}$ & 0.816 & $\star \star \star *$ \\
\hline Number of infertile eggs & $70^{a}$ & $48^{b}$ & $71^{a}$ & 0.816 & *** \\
\hline Percentage fertility (\%) & $77.4^{\mathrm{C}}$ & $82.0^{\mathrm{a}}$ & $80.4^{b}$ & 0.542 & $\star \star \star *$ \\
\hline Percentage infertility (\%) & $22.6^{\mathrm{a}}$ & $18.1^{\mathrm{c}}$ & $19.6^{\mathrm{b}}$ & 0.163 & *** \\
\hline
\end{tabular}

Means with different letters in the same row are significantly different $\left({ }^{*} P<0.001\right) ;$ s.e.d-Standard Error of difference

From Table 3, birds from Northern region produced more eggs than those from Upper East and Upper West. The high performance in egg production may be due to the relatively higher feed intake. Egg production in Upper West birds was lowest because of the low feed intake (Table 1). Alternatively the genetic makeup of the bird may also account for the differences in egg production. McGary et al. (2001) reported that genetic factors, chronic environmental and stress may adversely affect reproduction. Egg fertility in birds from all the three regions was good. This might be because the period of laying fell within the breeding/laying season. Maganga and Haule (1994) reported that the laying season for guinea fowls extends from April to September. Awotwi (1987) also indicated that the fertility of guinea fowl eggs ranges from $70-85 \%$ in the breeding season. This means that egg fertility between guinea fowls from all the regions are within the acceptable range of $70-85 \%$. Intensive selection based on individual outstanding performance coupled with well-planned crossbreeding programme is necessary to improve the meat and egg production potential of the indigenous guinea fowl (Teye et al., 2001).

\section{CONCLUSION:}

From the study, birds from Upper East ate less but had better body weight, higher survival rate and performed averagely better in terms of egg production than those from Upper West and Northern regions. Although performance of birds from Northern region was not much different from those from Upper East, they performed slightly better in terms of feed intake and egg numbers. Birds from Upper West performed poorly and this could be attributed to poor adaptation during the experimental period. Generally the performance traits of birds from the various regions varied and this can provide the basis for which they could be classified into breeds.

\section{REFERENCES}

Awotwi, E. K (1987). A review of studies on guinea fowls in Ghana. Department of Animal Science, University of Ghana, Legon. Legon Agric. Res. Bulletin 2:1-4.

Dei, H. K and Karbo, N (2004). Improving smallholder guinea fowl production in Ghana: A training Manual. Cyber Systems, Tamale, Ghana. 27pp.

Ayorinde, K. L and Oke, U. K (1995). The influence of juvenile body weight and two feeding regimes during the growing phase on growth performance and early lay characteristics of pullets. Nigerian Journal of Animal Production 22(2): 101 - 107.

Kashindye, F. A (2000). A study on the production potential of Guinea fowl in Tanzania. SUA Dissertation and thesis.

Maganga, S. L. S and Haule, K. S (1994). The domstiction of guinea fowl. A case study of Morogoro Municipal, Tanzania Wildlife and Nature. FAO International Journal on Nature Conservation in Africa 14: $14-28$.

McGary, S, Estevez, I and Ottinger, M. A (2001). Relationships between endocrine endpoints, reproductive behavior and fertility in two strains of primary broiler breeders. University of Maryland, College park, MD, USA.

Oke, U. K, Herbert, U. and Nwachukwu, E. N (2004). Association between bodyweight and some egg production traits in the guinea fowl (Numida meleagris galaeta palla). Livestock Research for Rural Development $16(9): 6$.

Savannah Agricultural Research Institute (SARI) (2004/2005). Meteorological Department. Council for Scientific and Industrial Research, Nyankpala, Tamale, Ghana.

Teye, G. A and Gyawu, P (2002). A guide to Guinea fowl Production in Ghana. 14pp.

Teye, G. A, Gyawu, P and Agbolosu, A. A (2001). Growth potential and carcass yield of exotic and indigenous guinea fowls in Ghana. In: Development Spectrum, an Inter-Faculty Journal of the University for Development Studies, Tamale. Volume 1: 34-40. 